\title{
The 'tamed' mountains: from terrifying and uninhabited environments to places of the soul and religious spaces
}

\author{
Francesco M. Cardarelli ${ }^{1}$ \\ ${ }^{1}$ National Research Council of Italy \\ Email:francesco.cardarelli@cnr.it
}

\begin{abstract}
The survey, by using the methods of historical research, focuses on the transformation of mountains, which, from terrifying and uninhabited environments, gradually became among the most significant places of the soul and religious spaces. Resorting to historical, literary and archival sources, the study, of an interdisciplinary nature, aims to reconstruct a little-known aspect of Italian history, in particular of history of culture and ideas.

Mountains, which constitute a significant portion of Italy, were considered by the Ancients antithetical to human civilization. With Christianity a new image of mountains made its way, where, according to the Scriptures, some decisive episodes of the history of salvation had taken place. The hermits who wanted to dedicate themselves only to God began to take refuge in the mountains, but the ideological prejudice transmitted by classical authors remained fixed in the collective imagination and upland areas continued for centuries to be misunderstood and rarely visited.

An important turning point came with two religious orders, the Camaldolese and the Franciscans, who gave a fundamental contribution to the 'taming' of mountains. Thanks to Saint Romuald, in Camaldoli, on the TuscanRomagnolo Apennines, an experience was born that combined evangelization, forest management and interventions on the mountain territory. In their settlements the Camaldolese, while cultivating the fields, regulating the waters and taking care of the woods, at the same time promoted education, culture and work for the people who lived nearby. From Assisi and the mountains of Umbria began the revolution of Saint Francis, which involved men and women, animals, fields, fruits, flowers, forests, rocks: all like God's creatures. Thus the Apennine mountains, the true backbone of the Italian peninsula, became increasingly popular open spaces, places of meeting and of spiritual and material life, based on a balanced and exemplary relationship between man and nature.
\end{abstract}

(C) 2019 The Authors. Published by IEREK press. This is an open access article under the CC BY license (https://creativecommons.org/licenses/by/4.0/).

\section{Keywords}

Mountains; Religion; Camaldolese; Saint Francis of Assisi

\section{Introduction. Civilization is inversely proportional to altitude}

Mountains, which constitute a significant portion of Italian territory, have acquired in the last few centuries a charm and a complex of particular meanings: today they are among the most significant places of the soul and religious spaces. But it hasn't always been this way: "for the Ancients mountains have had almost no interest" (Pellegrini, 1990, p. 372), and the various peaks or chains, with rare exceptions, did not even have a proper name until the eighteenth or nineteenth century. In Italy, and in general in Europe, the relationship between mankind and mountains has been marked for a very long time by ignorance, indifference and above all fear. 
Pagan gods lived in the mountains: in particular, on the top of Olympus in Thessaly, there was the abode of the twelve major deities, immutable and immortal for eternity. According to the Greeks, there was an absolute separation between the divine and the human sphere: the mortals who, driven by hubris, the "pride", tried to emulate the gods were punished severely. It was believed that upland areas were also frequented by other divine beings, for example the Nymphs, personifications of nature, distinguishable in various types, such as the Oreads, who lived specifically in the mountains, the Naiads, who lived near the springs and streams, and perhaps the Aquanae in the Alps, demonic creatures supposed the female equivalent of Silvanus (Alinei, 1985), the god of the woods venerated by the Romans. On the mountains lived also other monsters of various kind, such as the Centaurs and the Sileni, who stroke terror into man.

This gloomy representation of mountains, as a wild and demonic world, was also extended to inhabitants. On the basis of a rigid geographical determinism, "civilization was inversely proportional to altitude" (Giardina, 2004, p. 208): as elevation increased, so did the level of inhumanity and barbarity of populations. It is exemplary the way in which the greatest Latin historian, Titus Livius (59 BC - 17 AD), describes the Italic population of the Samnites, great enemies of the Romans, who "lived scattered throughout villages in the mountains", in the Apennine region of Samnium: "similar to the nature of the land where they lived, being wild mountaineers [montani atque agrestes] and despising the softer life conduct of the farmers, they devastated the plains and the regions along the coast" (Ab Urbe condita IX 13, 7).

The same ideological vision marks the largest ancient geographic treatise that has come down to us, written by Strabo (before $60 \mathrm{BC}$ - around $20 \mathrm{AD}$ ), a Romanized Greek. With regard to the Roman province of Lusitania, predominantly mountainous, Strabo writes: "most of the peoples of this region, disdaining to draw sustenance from the earth, devoted themselves to brigandage and an endless war between themselves and against neighboring peoples, crossing the Tagus; this until the Romans stopped them [...]. It was the mountaineers [oi ópevvoí] who began this life contrary to the laws, as is normal" (Geographica III 3, 5 [154]). Ultimately, for ancient authors "mountains and banditry were a

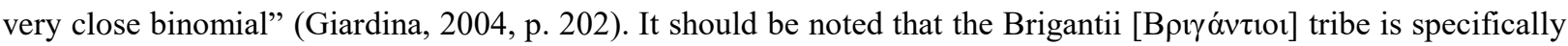
mentioned by Strabo among the Vindelici (Vindolici) and Reti populations, who lived in the mountains of the Central Alps, whose conduct is described with images full of horror: "The stories of the ferocity of these brigands towards the Italiotes are to this effect: after having conquered a village or a city, they not only kill men of young age, but also come to male children and do not desist even at that point, but also kill pregnant women who, according to the soothsayers, they will generate male children" (Geographica IV 6, 8 [206]).

\section{Christianity as a Mountain religion}

Compared to the religion of the Greeks and that of the Romans, Judaism and Christianity present a completely different conception of divinity and relationship with the sacred. Not only because of monotheism that characterizes the two religions of the Book (the Bible), but also because of the intimate link between God and humanity: the Creator entered into an alliance with the people of believers, called to salvation by fulfilling the Mosaic law (Old Testament) or accepting the evangelical message announced by Jesus Christ through the conversion of hearts (New Testament).

Judaism and Christianity are also two religions of the Mountain: from Abraham to Moses to Jesus Christ, mountains are the main scene of some decisive episodes in the history of salvation. Without considering various terms that indicate hills or rocks, "the Hebrew word har, 'mount, mountain', occurs 558 times: it is the 93rd word of the whole Hebrew lexicon by number of presences in Old Testament" (Ravasi, 2001, p. 17). On a mount of Ararat, Noah's ark rested after the Flood (Gen 8, 1-5); on the mount of Moria God tested Abraham asking him to sacrifice Isaac (Gen 22, 1-19). On the 'mountain of God' par excellence, Mount Sinai or Horeb, God called Moses from the burning bush and gave him the task of freeing the Jewish people from slavery in Egypt (Ex 2-4). On the same mountain the alliance between God and the people of Israel was contracted with the delivery of the Tables of the Law (Ex 19-31; 32-34). On Mount Carmel the prophet Elijah defeated idolatry (1 Kings 18); then he took refuge on Mount Horeb, where he met the Lord who renewed the alliance with Israel (1 Kings 19). In the Psalms Mount Sion - "which echoes 154 times in Old Testament" (Ravasi, 2001, p. 18) - is presented as the bedrock of Jerusalem and as the abode of God (Ps 2, 6; $48,2-4 ; 68,16-17 ; 76,3 ; 87,1-2)$; the same Mount Sion which, according to the prophets, will be the final goal of all 
peoples and the place of universal peace and messianic happiness (Isa 2, 2-5; 25, 6-10; 65, 17-25; Mic 4, 1-4; Zech 8, 3), as the Revelation will later confirm ( $\operatorname{Rev} 14,1 ; 21,10)$.

“The New Testament also has its mountains. On the statistical level the Greek word oros, 'mountain', occurs 63 times" (Ravasi, 2001, p. 18). On a very high mountain Jesus rejected the extreme temptation of the devil (Mt 4, 811); on a mountain he chose the twelve apostles (Mk 3, 13-18; Lk 6, 12-16) and proclaimed the beatitudes (Mt 5, 112) and the fundamental law of the Kingdom of Heaven (Mt 5-7; Lk 6, 17-49): Jesus, therefore, is the new Moses who offers the people the law of the new alliance. The parallelism between Jesus and Moses reaches its climax in the episode of the Transfiguration, which took place on a mountain (according to tradition, Tabor): at the end of the theophany only Jesus remained, the Son of God, the only teacher to listen to (Mt 17, 1-13; Mk 9, 2-13; Lk 9, 28-36). From the Mount of Olives Jesus began the Messianic entry into Jerusalem (Lk 19, 28-38; Mt 21, 1-11; Mk 11, 1-10), announced the destruction of Jerusalem, the end of the world and the Last Judgment (Mt 24-25; Mk 13). After the Last Supper, at the beginning of the Passion, he went to pray on the same mount (Lk 22, 39-46; Mt 26, 30-35; Mk 14, 26-31). Finally, after the crucifixion on the hill of Golgotha - Calvary according to Latin translation (Mt 27, 3256; Mk 15, 21-41; Lk 23, 26-49; Jn 19, 17-37) - Jesus, risen from the dead, ascended to Heaven from the same Mount of Olives (Acts 1, 6-12).

\section{The transmission of the prejudice of the Ancients along the Middle Ages}

With the advent of Christianity, in the East the hermits and monks who wanted to leave the things of the world to dedicate themselves only to God began to take refuge in desert places; in the West the equivalent of the desert was represented by mountains. In Italy already at the beginning of the Early Middle Ages "the mountain location of the monasteries is widespread and perhaps prevalent": yet, in the scarce written sources of the time there are no references to the 'mountain' episodes of the Holy Scriptures and the choice to create monastic settlements on mountains seems to be suggested above all "by concrete advantages (isolation, less interference from ecclesiastical and civil authorities, greater protection from attacks and raids)" (Pricoco, 2006, p. 273).

The only surviving testimony of the foundation of the most famous medieval abbey, that of Montecassino in the Central Apennines by Saint Benedict of Norcia (around 480 - after 546), is contained in a writing by Saint Gregory the Great (about 540 - 604). The pope's story reveals that the ideological prejudice transmitted by classical authors mountains and their inhabitants are the antipodes to the human and civil world - had crystallized into a real stereotype, rooted in the collective imagination: "The fortified place, called Cassino, is located on the side of a high mountain. [...] There was a very ancient place of worship, in which following the ancient pagan tradition the farmers foolishly worshiped Apollo. Around them were grown woods consecrated to the worship of demons, in which at that time a crowd of pagans devoted themselves with insane zeal [the verb used is the rare insudabat, to emphasize an intense, 'sweaty' commitment] to sacrilegious sacrifices. Arriving in that place, the man of God [Saint Benedict] tore the idol apart, overturned the altar, cut the woods" and created a place of Christian worship (Dialogi II, 8, 10-11 = Gregorius Magnus, 2006, p. 140-1).

About five centuries later the words used by Rodulfus Glaber (circa 985 - perhaps 1047) sound very similar. In his chronicles about time around the Year One Thousand he dwells on an episode that took place "in the area of the Alps, where the allocations of primitive populations [brute gentes] are frequent, mostly in inaccessible places" and where the "populace" is afflicted by "mental inertia, that is typical of uncivilized people". The monk thus concludes: "We have told this story to warn against the many forms of demonic apparitions, or human illusions, which abound in every corner of the earth, but above all near the springs and among the trees, and which become the object of ruthless veneration by the sick" (Historiae IV, 6-8 = Rodulfus Glaber, 1999, p. 206-7; 210-3).

Thus, although Alpine and Apennine landscapes were progressively marked by Christian signs, mountain regions territories as a whole continued to be misunderstood and little frequented: hermitages and monasteries seemed more places of refuge and 'islands' of individual salvation in hostile environments than centers of radiating the Gospel message. 


\section{The Camaldolese and the forest: a monasticism open to the world}

An important turning point came with the Camaldolese and the Franciscans: these two religious orders, following the teachings of the respective founders, made a fundamental contribution to the 'taming' of mountains.

Saint Romuald of Ravenna (951/953 - 1027) was a charismatic figure of the Benedictine Order: between 1023 and 1026, in the upper Casentino, in the heart of the Tuscan-Romagnolo Apennines, Romuald built a hermitage in the middle of a forest in the locality then called Camaldoli, at about $1000 \mathrm{~m}$ of altitude. Shortly after, three kilometers below, he founded a monastery, which was to constitute a filter between the hermitage and the 'world', in addition to becoming the place dedicated to the administration of goods and the reception of guests, pilgrims and sick people. While until then the monastery was considered a sort of citadel closed to the outside, reserved only to religious people who sought spiritual perfection, Romuald wanted to "convert the whole world into a hermitage" (Vita beati Romualdi XXXVII = Petrus Damiani, 1957, p. 78), as we read in the first biography of the saint of Ravenna, written by Peter Damian (1006 or 1007 - 1072). In the development of the new religious movement, alongside Camaldoli, an important role was played by Fonte Avellana, a hermitage founded "in the desert of Mount Catria, in the impervious Apennines on the border between Marche and Umbria [...], in all probability under the influence of the reforming activity of Romuald", which then received an extraordinary impulse by the young prior Peter Damian, who, "in the wake of his model Romuald, [...] advocat[ed] a monasticism open to the world" (Longo, 2015, p. 304-5).

"Since their first establishment in Camaldoli, Romualdine monks-hermits had a privileged relationship with the forest, a symbol of solitude and communion with the entire creation" (Cardarelli, 2004b, p. 3-4). In the Liber Eremitice Regule, a legislative text of the Camaldolese Congregation of the second half of the twelfth century, we read: "Among the many forms of religious life [...] the solitary life undoubtedly occupies the first place" ( $L E R$, Prologue = Licciardello, 2004, p. 22-3). And there are some examples of great figures who sought solitary life in the desert and the mountains. First of all Moses, who "laid the foundations of this life leaving the crowd in the fields and climbing up the mountain" (LER, I = Licciardello, 2004, p. 24-5); then Elijah, who in the desert "walked forty days and forty nights to the mountain of God, Horeb, where he deserved the relief of the vision of God" ( $L E R$, II = Licciardello, 2004, p. 26-7). Thus the Savior, who in the desert at first alone "consecrated this form of life with his example. [...] Later, often climbing on the mountain, sometimes alone, sometimes in prayer with a few disciples, he showed us an imitable example of this form of life" (LER, V = Licciardello, 2004, p. 30-1). The ancient fathers are then mentioned, who "shone with the glory of God" in the deserts and the mountains (LER, VI = Licciardello, 2004, p. 30-1); before dwelling on the teaching of Saint Benedict and Saint Romuald, even ancient philosophers are taken as examples, who "embraced with great passion the life withdrawn [...] in inaccessible places" (LER, VII = Licciardello, 2004, p. 301). The chapter entitled The meaning of the seven trees proposes the existential identification of the Camaldolese with the "seven trees planted by God in the desert" (LER, XLVI = Licciardello, 2004, p. 70-1), mentioned by the prophet Isaiah $(41,19)$ according to the exegesis of Gregory the Great: "to acquire the necessary virtues in the search for perfection, the hermit must 'become' himself a cedar, an acacia, a myrtle, an olive tree, a fir tree, an elm and a boxwood, in a process of authentic symbiosis between man and the natural environment" (Cardarelli, 2004b, p. 4).

According to the rules of the Congregation, work plays a central role in the sanctification of the Camaldolese monkhermit, alongside prayer and contemplation, giving rise to a singular experience that combined eremitical life, evangelization, forest management and interventions on mountain areas (opening of roads, construction of bridges, regulation of water courses, woodland and agricultural cultivations). The Camaldolese proved to be careful administrators of timber and other wood and earth products so much so that their numerous charitable and welfare works (hospices, hospitals and so on) were primarily supported by the profits made by the great agricultural-forestry 'company' of Camaldoli. The desire to conserve, expand and enrich the woodland with care and competence has produced over the centuries a series of extremely interesting rules concerning silviculture, which is indicated with the phrase "Camaldolese Forest Code" (Cacciamani, 1965). With the proliferation of Romualdine foundations in the areas of central Italy (Cacciamani, 1963), the set of rules issued by the Camaldolese to regulate the management and preservation of forests according to a balanced relationship between man and nature became a model in Apennine silviculture (Cardarelli, 2004a). In their settlements the Congregation at the same time promoted education, culture 
and work for the people who lived nearby: around their monasteries, especially in Tuscany, villages and little towns quickly developed.

\section{Francis of Assisi: the mountains 'liberated' from the ancient cultural prejudice}

About two centuries after Saint Romuald, another great religious reformer played an important role in the metamorphosis of the image of mountains, thanks to his 'inclusive' conception of holiness. In the thirteenth century from Assisi and Umbria began the revolution of Saint Francis (1181 or 1182 - 1226), which involved men and women, animals, fields, fruits, flowers, forests, rocks: all like God's creatures.

Francis knew and frequented the Apennine mountains assiduously, beginning with those surrounding Assisi - the Subasio on all - where he sought refuge to meditate and pray in solitude. One reads in the Vita beati Francisci, the first biography of the saint written by Thomas of Celano (around 1190 - around 1260): "he made the nest between the hiding places of the cliffs and his house was in the rocky caves. [...] Therefore he often chose solitary places to be able to direct his whole spirit in God but, when he saw the opportune time, he did not hesitate to face the difficulties and to dedicate himself to the salvation of his neighbor" (Thomas de Celano, 71, 3-5 = Leonardi, 2005, p. 140-3). In the writings certainly attributable to Saint Francis mountains are never mentioned. And yet, there is no doubt that, even if not explicitly mentioned, mountains belong fully to "our sister mother earth", as creation is defined in the Cantico di frate sole. The Vita beati Francisci confirms this: "And when he met an expanse of flowers, he preached to them and invited them to praise the Lord as if they had reason. So also the crops and the vineyards, the stones and the woods and all the beautiful countryside, the irrigated sources and every green garden, the earth and the fire, the air and the wind exhorted with sincere purity to love God and to obey him promptly" (Thomas de Celano, 81, 3-4 = Leonardi, 2005, p. 156-7). According to the same biography, the preparation of the crib in Greccio originated from the "maximum aspiration" of Francis "to practice perfectly the teaching of our Lord Jesus Christ and follow in his footsteps". This explains the miracle of reviving the Nativity in the mountain woods at night: "Greccio becomes almost a new Bethlehem. The night shines like the day and is delicious to men and animals. The crowds arrive [...]. The wood resounds with voices and the rocks echo the cheers of joy" (Thomas de Celano, 84, 1; 85, 5-8 = Leonardi, 2005 , p. 160-1; 162-5). It was something never seen before.

Speeches and writings of Francis of Assisi are interwoven with biblical quotations, which seem to flow spontaneously and authentically from his heart and from his mouth. In his Testamentum he states that his words were to be understood sine glossa, "without comment", and followed to the letter. "The writings document, without a possible shadow of doubt, that in the last few years Francis, collapsed from illness and pain, from a tormented and tortured physical life, was pervaded by a deep and irrepressible joy for a single reason: the awareness of having been transformed in the divine, to truly be another Christ, in the fullness of knowing oneself become the Son of God in the Son-Word made flesh" (Leonardi, 2004b, p. XXXIX). Of this unparalleled mystical experience, the stigmata, imprinted on his body on the mountain of La Verna in September 1224, represented the definitive seal. This novelty turned out to be shocking even for contemporaries. The Epistola encyclica de transitu sancti Francisci, the letter with which Elias of Cortona (1170/1180 circa - 1253) announces to the Franciscan Order the death of the founder, reads: "From what world and world has never been heard to say that it is appeared the sign that I am going to tell you, except in the Son of God, who is Christ God. Shortly before death our brother and father [Francis] appeared crucified, carrying on his body the five wounds, which are the true stigmata of Christ" (Helias Cortonensis, 16-17 = Leonardi, 2004a, p. 2501). In short, Francis of Assisi could be considered almost an alter Christus, a "new Christ". This unprecedented similarity was deepened by the Franciscans, in particular by Saint Bonaventure of Bagnoregio (1217 circa - 1274), who in the Itinerarium mentis in Deum, one of the highest works of medieval spirituality, proposes the ascent towards God under the sign of Francis, the saint who had reached the perfection of the Christian life. The Itinerarium was composed on the mountain of La Verna, the same place where Francis had "concluded his journey with a perfect imitation and a spiritual and bodily transformation in Christ" (Leonardi, 2013b, p. 8). Later the same Doctor Seraphicus wrote the Legenda maior sancti Francisci where establishes a close connection between Mount Sinai, La Verna and the mountain of the Transfiguration: the stigmata are almost like a "bubble of the supreme pontiff Christ" (Bonaventura Bagnoregis, IV 11, 10 = Leonardi 2013a, p. 90-1) and Saint Francis, after the experience on the mountain, has truly become a whole with Lord Jesus. 
"Among his numerous merits, Francis also has contributed to changing [...] the history of mountains, meaning the history of the relationship between men and 'highlands' [...] because, thanks to his action and preaching, mountains were 'liberated' from the ancient cultural prejudice that weighed on them" (Cardarelli, 2019, p. 1552). Francis of Assisi, following Jesus in an integral way, with his complete sequela Christi proposed to all people, showed that everyone could seek God not indoors, but outdoors, in the solitude of the desert and the mountains. This led to a profound change in mentality: along the Apennines, the true backbone of the Italian peninsula, in the footsteps of Saint Francis, religious and lay people began to open new spaces of prayer, conviviality and meeting, places of spiritual life and material assistance. Moreover, the Franciscan revolution, at least in the beginning, was also characterized by the lack of 'walls' and divisions: "To renounce, in the early thirteenth century, walls, gratings, dividing walls or fences and in general any kind of concrete and symbolic sign of the fuga e seculo ["escape from the world"], it means overcoming centuries of history, rejecting one of the fundamental and constant elements of the medieval tradition" (Romanini, 1987, p. 478).

\section{Conclusions. Dante and the irreversible 'taming' of mountains}

Mountains had regained their allegorical and emblematic value of upward tension and contact between Earth and Heaven, as evidenced by the greatest poem of Italian literature, the Divine Comedy. Dante Alighieri (1265 - 1321) speaks of the hermitage of Camaldoli in Purgatorio (V, 94-96), through the words of Buonconte of Montefeltro (1250/1255 circa - 1289), and of the hermitage of Fonte Avellana in Paradiso (XXI, 106-111), by the mouth of Saint Peter Damian, while Saint Benedict glorifies Saint Romuald in the next canto of the same third part (XXII, 49). In canto XI an unparalleled eulogy of Francis of Assisi is traced: he is called "a sun" (XI, 50) with a very powerful Christological image; in the penultimate canto of the same Paradiso (XXXII, 28-36) the saint is placed "in the white rose of the Empyrean facing Mary, in the step immediately below the one occupied by Saint John the Baptist, followed by Saint Benedict, Saint Augustine and others not named” (Stanislao da Campagnola, 2005, p. 286).

Therefore, it is not too surprising that Dante imagined that the journey to Heaven was preceded by the ascension of Purgatory. Cato orders the souls: "Run to the mountain" (Purgatorio II, 122), so that by climbing the highest mountain they will purify themselves from sins and worldly habits that prevent the vision of God. Another significant Dantesque innovation is to represent on the summit of Purgatory the earthly Paradise, the Eden, to be identified "with the state of happiness attainable in earthly life through the use of moral virtues" (Ciotti, 2005, p. 285). And in the earthly Paradise the coveted meeting of the poet with Beatrice took place, a premise to the final ascent into the heavenly Paradise. So the ascent of the mountain becomes a decisive step towards the salvation of the pilgrim Dante, whose exemplary path is projected on all humanity. The 'taming' of mountains has now become an irreversible process: being part of the natural and physical environment, and being at the same time symbolic and utopian places, mountains can henceforth fully develop their dual nature, with a creative power that will prove extraordinary and will permeate the entire modern era.

\section{References}

Alinei, M. (1985). Silvani latini, Aquane ladine: dalla linguistica all'antropologia. In: Kindl U, editor. Le leggende fassane di Hugo de Rossi. Atti del Convegno di studio (Vigo di Fassa, 20-21 Aprile 1985). Mondo ladino; 9(3-4): 49-78.

Bonaventura Bagnoregis. (2013a). Legenda maior sancti Francisci. In: Leonardi C, editor. La letteratura francescana. IV. Bonaventura: la leggenda di Francesco. Translation by Donnini M, Commentary by Solvi D. Milano: Fondazione Lorenzo Valla-Arnoldo Mondadori Editore; p. 332333 (Latin text with Italian translation); 337-400 (commentary).

Cacciamani, GM. (1963). Atlante storico-geografico Camaldolese con 23 tavole (secoli X-XX). [Camaldoli, Poppi]: Edizioni Camaldoli.

Cacciamani, GM. (1965). L'antica Foresta di Camaldoli. Storia e codice forestale. [Camaldoli, Poppi]: Edizioni Camaldoli.

Cardarelli, F, editor. (2004a). Il Codice forestale camaldolese. Legislazione e gestione del bosco nella documentazione d'archivio romualdina. Roma-Bologna: Istituto Nazionale della Montagna-Bononia University Press.

Cardarelli, F. (2004b). Il Codice forestale camaldolese: un'introduzione. In: Cardarelli F, editor. Il Codice forestale camaldolese. Legislazione e gestione del bosco nella documentazione d'archivio romualdina. Roma-Bologna: Istituto Nazionale della Montagna-Bononia University Press. p. 1-11.

Cardarelli, F. (2019). Dal Cantico di frate sole alla sequela di Gesù Cristo «sine glossa»: il ruolo di Francesco d'Assisi nella metamorfosi dell'immagine della montagna. In: Salvatori F, editor. L'apporto della Geografia tra rivoluzioni e riforme. Atti del XXXII Congresso Geografico Italiano (Roma, 7-10 Giugno 2017). Roma: A.Ge.I. p. 1547-53. 


\section{Cardarelli / Proceedings of Science and Technology}

Ciotti, A. (2005). Paradiso terrestre. In: Enciclopedia Dantesca. Special edition for Biblioteca Treccani. Roma-Milano: Istituto della Enciclopedia Italiana-Arnoldo Mondadori Editore. Vol. 12. p. 284-7.

Giardina, A. (2004). Uomini e spazi aperti. In: Giardina A, L'Italia romana. Storie di un'identità incompiuta. Roma-Bari: Editori Laterza. p. 193232.

Gregorius Magnus. (2006). Storie di santi e di diavoli (Dialoghi). I (Libri I-II). Introduction and Commentary by Pricoco S; Critical text and translation by Simonetti M. 2nd ed. Milano: Fondazione Lorenzo Valla-Arnoldo Mondadori Editore.

Helias Cortonensis. (2004a). Epistola encyclica de transitu sancti Francisci. In: Leonardi C, editor. La letteratura francescana. I. Francesco e Chiara d'Assisi. Commentary by Solvi D. Milano: Fondazione Lorenzo Valla-Arnoldo Mondadori Editore. p. 248-55 (Latin text with Italian translation by Ricci LGG); 481-6 (commentary).

Leonardi, C. (2004b). Introduzione. Francesco d'Assisi. In: Leonardi C, editor. La letteratura francescana. I. Francesco e Chiara d'Assisi. Commentary by Solvi D. Milano: Fondazione Lorenzo Valla-Arnoldo Mondadori Editore. p. XIII-L.

Leonardi, C. (2013b). Legenda maior sancti Francisci. Introduzione. In: Leonardi C, editor. La letteratura francescana. IV. Bonaventura: la leggenda di Francesco. Translation by Donnini M, Commentary by Solvi D. Milano: Fondazione Lorenzo Valla-Arnoldo Mondadori Editore. p. 5-30.

Liber Eremitice Regule (LER). (2004). In: Licciardello P, editor. Consuetudo Camaldulensis: Rodulphi Constitutiones, Liber Eremitice Regule. Critical edition and translation. Firenze: SISMEL Edizioni del Galluzzo. p. 22-81 (Latin text with Italian translation); 88-107 (comment notes).

Longo, U. (2015). Pier Damiani (Petrus Damiani, Petrus peccator), santo. In: Dizionario Biografico degli Italiani. Roma: Istituto della Enciclopedia Italiana. Vol. 83. p. 303-12.

Pellegrini, GB. (1990). Toponomastica italiana: 10.000 nomi di città, paesi, frazioni, regioni, contrade, fiumi, monti spiegati nella loro origine e storia. Milano: Hoepli.

Petrus Damiani. (1957). Vita Beati Romualdi. Latin text edited by Tabacco G. Roma: Istituto Storico Italiano.

Pricoco, S. (2006). Commento. In: Gregorius Magnus. Storie di santi e di diavoli (Dialoghi). I (Libri I-II). Introduction and Commentary by Pricoco S; Critical text and translation by Simonetti M. 2nd ed. Milano: Fondazione Lorenzo Valla-Arnoldo Mondadori Editore. p. $219-377$.

Ravasi, G. (2001). I monti di Dio. Il mistero della montagna tra parola e immagine. Cinisello Balsamo: Edizioni San Paolo.

Rodulfus Glaber. (1999). Cronache dell'Anno Mille (Storie). Edition of the Latin text and Italian translation by Cavallo G, Orlandi G. 6th ed. Milano: Fondazione Lorenzo Valla-Arnoldo Mondadori Editore.

Romanini, AM. (1987). Monachesimo medievale e architettura monastica. Introduzione. In: Alessio GC et al. Dall'eremo al cenobio. La civiltà monastica in Italia dalle origini all'età di Dante. Milano: Libri Scheiwiller-Credito Italiano. p. 423-85.

Stanislao da Campagnola. (2005). Francesco di Assisi, santo. In: Enciclopedia Dantesca. Special edition for Biblioteca Treccani. Roma-Milano: Istituto della Enciclopedia Italiana-Arnoldo Mondadori Editore. Vol. 9. p. 286-94.

Thomas de Celano. (2005). Vita beati Francisci. In: Leonardi C, editor. La letteratura francescana. II. Le vite antiche di san Francesco. Commentary by Solvi D. Milano: Fondazione Lorenzo Valla-Arnoldo Mondadori Editore. p. 30-263 (Latin text with Italian translation by Solvi D); 497548 (commentary) 